Матеріали Всеукраїнської науково-практичної конференчії «Актуальні питання діагностики, лікування, рачіональної фармакотерапії, диспансеризації та реабілітації в практиці сімейного лікаря»

УДК 614.2:616-08-039.57

DOI

\title{
ДО ПИТАННЯ ОПТИМІЗАЦІЇ ПЕРВИННОЇ ЛАНКИ СИСТЕМИ ОХОРОНИ ЗДОРОВ'Я
}

\author{
○В. Л. Смірнова, Н. Я. Панчишин, Н. О. Теренда, О. Я. Галицька-Хархаліс,
} О. Н. Литвинова, Ю. М. Петрашик

ДВНЗ «Тернопільський державний медичний університет імені І. Я. Горбачевського МОЗ України»

Вступ. Складові моделі реформування первинної медичної допомоги (ПМД) полягають у юридичному та фінансово-економічному розмежуванні первинної допомоги та медичної допомоги інших рівнів. Надання ПМД мають забезпечувати центри ПМД, а також лікарі загальної практики - сімейні лікарі.

Передбачене реформами зміщення уваги зі спеціалізованої на первинну медичну допомогу потребує підготовки лікарів загальної практики або сімейних лікарів, які 6 надавали більшу кількість базових послуг, проводили профілактику, ранню діагностику та координували лікування пацієнтів. Підготовку таких спеціалістів розпочали одночасно двома способами: реформування медичної освіти в медичних вишах та перепідготовка практикуючих терапевтів, педіатрів та інших спеціалістів.

Мета дослідження. Аналіз відвідуваності первинної ланки медичної допомоги населенням Тернопільської області та організаційної структури центрів ПМД.

Матеріал і методи дослідження. Статистичні облікові документи амбулаторно-поліклінічних закладів Тернопільської області. Методи: статистичні, соціологічні, інформаційно-аналітичні, системний аналіз.

Результати й обговорення. Основним підрозділом в наданні ПМД є центр ПМД для організації надання населенню територіальної громади району безоплатної ПМД та забезпечення організаційно-методичної роботи. Вони включають в себе лікарські амбулаторії, амбулаторії загальної практики/сімейної медицини, відділення лікарів загальної практики/сімейної медицини, сімейних та дільничних лікарів, фельдшерськоакушерські, фельдшерські та медичні пункти. У населених пунктах з чисельністю населення до 300 осіб створюються медичні пункти, а з чисельністюнаселення від 300 до 800 осі6-фельдшерські а6о фельдшерсько-акушерські пункти. Причому медичні пункти, фельдшерські та фельдшерськоакушерські пункти необхідно розглядати як проміжний етап реформування первинної медичної допомоги. В кінцевому варіанті структурної організації первинної медичної допомоги в медичних пунктах повинні працювати помічники сімейних лікарів, а на базі фельдшерсько-акушерських пунктів, які обслуговують 1200 і більше населення, будуть створені амбулаторії загальної практики/сімейної медицини.

Ми вивчали відвідуваність амбулаторно-поліклінічних закладів населенням Тернопільської області, була проведена корекція цих відвідувань з урахуванням запровадження сімейної медицини. На кожну 1000 мешканців було здійснено 7411,2 відвідування амбулаторно-поліклінічних закладів або 7,4 відвідування на 1 мешканця. Більше половини цих відвідувань $(54,7$ \%) припало на дільничних лікарів-терапевтів і педіатрів. Серед фахівців вузького профілю найбільше звернень було до хірургів (8 \%), отоларингологів (7,9\%), неврологів (6\%), акушерів-гінекологів (4,4\%), окулістів (3,9 \%) - загалом майже третина усіх відвідувань, що зумовлено, на наш погляд, з одного боку, поширеністю відповідної патології, з іншого - багаторічною практикою участі цих фахівців у профілактичних оглядах населення.

Відвідуваність в умовах сімейної медицини має бути суттєво скоригована. Частка звернень до сімейного лікаря має бути підвищена до $84,6 \%$, на частку фахівців вузького профілю залишається лише 15,4 \% відвідувань. Частка наведених вище фахівців вузького профілю зменшена з 30,9 до 8,6 \% або в 3,6 раза; аналогічно різко зменшена кількість звернень до фахівців терапевтичного профілю - з 5,6 до 0,9 \% відвідувань, або в 6,2 раза.

Водночас слід зауважити, що відвідуваність онкологів і фтизіатрів залишається приблизно на тому ж рівні, а психіатрів-наркологів навіть зросла на $16,9 \%$.

Робота центрів ПМД полягає в забезпеченні населення доступною, безперервною, своєчасною, якісною та ефективною первинною медичною допомогою. Створення мережі амбулаторій у складі центру ПМД може здійснюватися у трьох варіантах: централізованому, при якому організація відбувається на базі однієї з поліклінік, коли амбулаторії функціонують як невідокремлені структурні підрозділи центру; децентралізованому, коли практично всі амбулаторії, окрім однієї, розташованої на території центру ПМД, функціонують як відокремлені структурні підрозділи центру та мають різні юридичні адреси; змішаному, коли частина амбулаторій розташовується на базі 
Матеріали Всеукраїнської науково-практичної конференції «Актуальні питання діагностики, лікування, раціональної фармакотерапії, диспансеризації та реабілітації в практиці сімейного лікаря»

центру, частина - на базі іншої великої поліклініки також з організацією для кожної з них окремого входу, частина - на базі спеціально створених амбулаторій.

Створення центрів ПМД забезпечить реалізацію права громадян вільно вибирати лікаря; належну доступність, якість та рівність у отриманні ПМД для прикріпленого населення шляхом розвитку мережі підрозділів, наближених до місць проживання населення, що $є$ надзвичайно важливим, особливо для сільської місцевості; наступність та послідовність обстеження, лікування та реабілітації пацієнтів у взаємодії з іншими закладами охорони здоров'я відповідно до медичного маршруту пацієнта; профілактику та раннє виявлення неінфекційних та соціально-небезпечних захворювань.
Висновки. Перехід до оптимізації первинної ланки системи охорони здоров'я вимагає радикального перегляду організаційних основ чинної системи медичної допомоги, руйнування психологічних стереотипів тощо. Виникають, на наш погляд, проблеми, які мають бути розв'язані: належна підготовка сімейного лікаря, відповідне матеріально-технічне забезпечення лікарської амбулаторії і набуття нею самостійного адміністративного, юридичного і фінансового статусу.

Формування мережі амбулаторій, які входять до складу центру ПМД може здійснюватися за одним з трьох варіантів: централізованим, децентралізованим та змішаним.

Перспективи подальших досліджень полягають у поглибленому вивченні організаційних основ системи медичної допомоги на первинному рівні. 